\title{
Quantification of Microplastics in North-Western Mediterranean Harbors: Seasonality and Biofilm-Related Metallic Contaminants
}

\author{
Javier A. Tesán Onrubia ${ }^{1, *}$, Kahina Djaoudi ${ }^{1,2}$, Franco Borgogno ${ }^{3} \mathbb{D}$, Susanna Canuto ${ }^{3}$, Bernard Angeletti ${ }^{4}$,

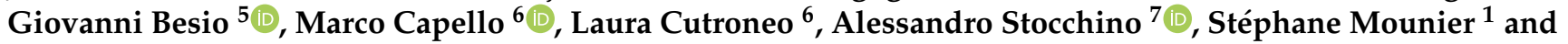 \\ Véronique Lenoble ${ }^{1, *(1)}$
}

check for updates

Citation: Tesán Onrubia, J.A.;

Djaoudi, K.; Borgogno, F.; Canuto, S.; Angeletti, B.; Besio, G.; Capello, M.; Cutroneo, L.; Stocchino, A.; Mounier, S.; et al. Quantification of Microplastics in North-Western Mediterranean Harbors: Seasonality and Biofilm-Related Metallic Contaminants. J. Mar. Sci. Eng. 2021, 9, 337. https://doi.org/10.3390/ jmse9030337

Academic Editors

Olivier Radakovitch and Qing Wang

Received: 23 January 2021

Accepted: 16 March 2021

Published: 19 March 2021

Publisher's Note: MDPI stays neutral with regard to jurisdictional claims in published maps and institutional affiliations.

Copyright: (C) 2021 by the authors. Licensee MDPI, Basel, Switzerland. This article is an open access article distributed under the terms and conditions of the Creative Commons Attribution (CC BY) license (https:// creativecommons.org/licenses/by/ $4.0 /)$.
1 Aix-Marseille University, Université de Toulon, CNRS, IRD, MIO UM 110, 13288 Marseille, France; djaoudikahina@gmail.com (K.D.); stephane.mounier@mio.osupytheas.fr (S.M.)

2 Department of Molecular and Cellular Biology, University of Arizona, Tucson, AZ 85721, USA

3 European Research Institute, Via Pinelli 24/d, 10144 Torino, Italy; b.franco@eri.net.in (F.B.); c.susanna@eri.net.in (S.C.)

4 Aix-Marseille University, CNRS, IRD, INRA, Coll France, CEREGE, 13110 Aix-en-Provence, France; angeletti@cerege.fr

5 Dipartimento di Ingegneria Civile, Chimica e Ambientale, Università degli Studi di Genova, 1 Via Montallegro, 16145 Genoa, Italy; giovanni.besio@unige.it

6 Dipartimento di Scienze della Terra dell'Ambiente e della Vita, Università degli Studi di Genova, Corso Europa 26, 16132 Genova, Italy; marco.capello@unige.it (M.C.); laura.cutroneo@edu.unige.it (L.C.)

7 Department of Civil and Environmental Engineering, The Hong Kong Polytechnic, University, Hung Hom, Kowloon, Hong Kong, China; alessandro.stocchino@polyu.edu.hk

* Correspondence: javier.tesan@mio.osupytheas.fr (J.A.T.O.); lenoble@univ-tln.fr (V.L.)

Abstract: The Mediterranean Sea is one of the most impacted basins in terms of microplastics pollution. Land-based activities are the major sources of plastic litter to the ocean, with harbors probably representing significant hotspots. In the framework of the SPlasH! project (Stop alle Plastiche in $\mathrm{H}_{2} \mathrm{O}$, Interreg Marittimo project), microplastics were sampled in three north-western Mediterranean harbors during summer and winter. In this study, the areal concentrations of microplastics ranged from 5576 to 379,965 items $\cdot \mathrm{km}^{-2}$. A decreasing gradient was observed from the inner to the outer zones of the studied harbors, pointing out these enclosed systems as hotspots regarding microplastic pollution. During summer, the areal concentrations of microplastics were higher than in winter, which could be explained by an enhancement of port activities leading to MPs production. The investigation of microplastics size classes distribution in the surface waters revealed that microplastics within the size range between $300 \mu \mathrm{m}$ and $500 \mu \mathrm{m}$ were the least represented. In this study, we assessed trace metal $(\mathrm{Pb}, \mathrm{Fe}, \mathrm{Cu}, \mathrm{V}, \mathrm{Cd}$ and $\mathrm{As})$ bioaccumulation by the biofilm which developed on the surface of microplastics. The results highlighted that concentrations within the biofilm were higher than those in the surrounding waters. This result strongly suggested trace metal bioaccumulation on microplastics through biofilm formation. When trace metal concentrations were normalized over the corresponding surface of microplastics and macroplastics, higher values were obtained for microplastics, evidencing their enhanced capacities to bioaccumulate contaminants when compared to macroplastics.

Keywords: microplastic; harbor; trace metal; Mediterranean Sea; biofilm; bioconcentration

\section{Introduction}

Microplastics (MPs) are artificial particles of plastic within a size range below $5 \mathrm{~mm}$. Because of their wide distribution over the global ocean, MPs pollution and its impact on ecosystems is getting an increasing attention. Plastics have been mass-produced since the 60 's, with a substantial increase observed during the last years [1], thus resulting in the MPs widespread in marine environments. MPs are defined as primary microplastics when 
they are emitted in the form of scrubbing agents or secondary microplastics when they result from the degradation of larger plastics, by photodegradation, mechanical abrasion and/or weathering for example [2].

The Mediterranean Sea hosts 17,000 species, thereby contributing by 7\% to the world's ocean biodiversity [3]. On the other hand, human impacts have contributed to threaten this ecosystem since the industrial revolution, resulting in habitat destruction, pollution and eutrophication [4]. The Mediterranean Sea is an oceanic basin representative of an enclosed mini-ocean. Its own conveyor belt and its fast circulation with respect to the global ocean make it highly reactive to external forcing, especially matter fluxes at the interfaces [5]. In fact, in terms of MPs pollution, the Mediterranean Sea is one of the most impacted basins within the global ocean [6,7], with reported concentrations comparable to those of the subtropical ocean gyres [8]. These high concentrations are the result of high human pressure, resulting from land-based plastic wastes [9] and of the long residence times of surface waters [7].

In these populated and industrialized coastal areas, harbors are receiving MPs inputs from the coast, therefore representing hotspots for plastic pollution $[9,10]$ and consequently sources to the open ocean. Furthermore, harbors gather industrial and transport activities, an additional source of MPs into local waters but also to the open sea [11]. Today, although there is evidence that MPs pollution could have a strong impact on harbors ecosystems, its magnitude is still poorly resolved.

In seawater, MPs are rapidly colonized by marine microorganisms, which adhere to their surface through a complex matrix of extracellular polymeric substances (EPS) including, among others, polysaccharides, proteins, lipids and DNA [12], forming a biofilm. This 3D-structure offers microorganisms a protective layer from the external environment [13]. Inorganic contaminants can bioaccumulate on the biofilm through complexation with bacterial EPS, occurring at the surface of the cells, or through intracellular biosorption [14]. Hence, biofouled MPs can bioaccumulate inorganic and organic contaminants [15,16], increasing their chance to enter food webs [17]. In this way, MPs, being disseminated through currents, can be a vector pathway for contaminants over large spatial scales but also through trophic networks if ingested.

In the framework of the INTERREG-Italia-France Marittimo Splash! Project (Stop alle Plastiche in $\mathrm{H}_{2} \mathrm{O}$ !, http: / /interreg-maritime.eu/web/splash (accessed on 16 December 2020)), three north-western Mediterranean harbors: Toulon (TLN) in France, Genova (GEN) and Olbia (OLB) in Italy were sampled in winter (W) 2018 and summer (S) 2019 in order to characterize MPs pollution and biofilm-related inorganic contaminants.

\section{Materials and Methods}

\subsection{Sampling}

Toulon is an urban area in the south-eastern France, with approximately 600,000 inhabitants. The bay is a shallow semi-enclosed area, separated in two parts by a dyke (Figure 1$)$. The small bay $\left(10 \mathrm{~km}^{2}\right)$, at the west, is close to the town and thus mostly hosts all the anthropogenic activities (marina, industry, commercial traffic, French Navy, raw sewage and mussel farms). The large bay $\left(42 \mathrm{~km}^{2}\right)$, at the east, is connected to the offshore which favors water exchange [18]. Two rivers flow into the bay of Toulon. In the western part, the Las river and in the eastern part the Eygoutier, with drainage basins of $60 \mathrm{~km}^{2}$ and $70 \mathrm{~km}^{2}$, respectively. 


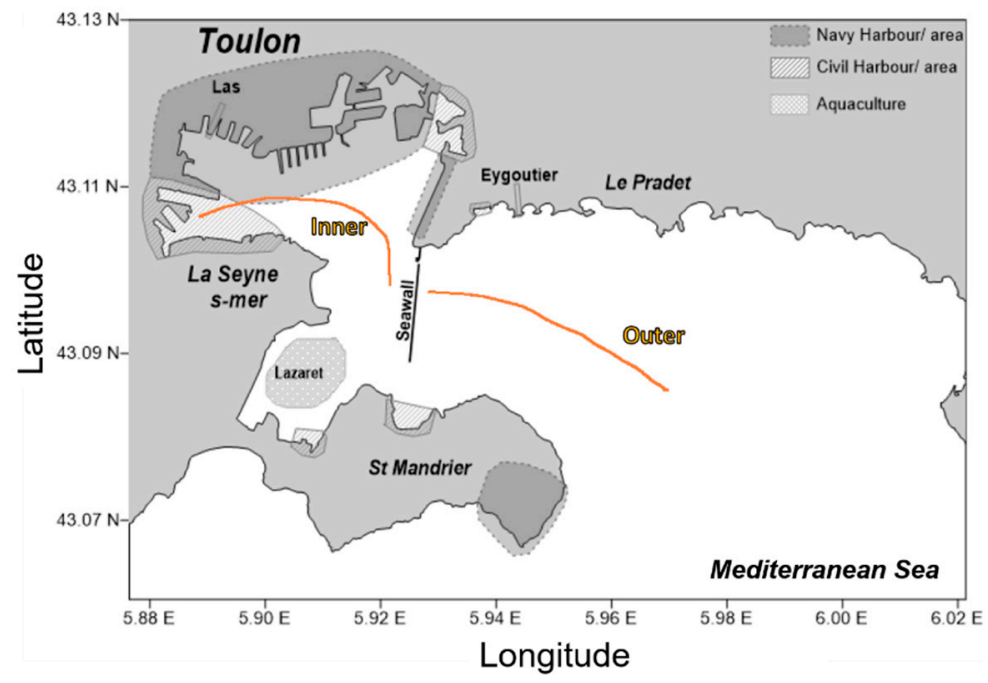

(a)

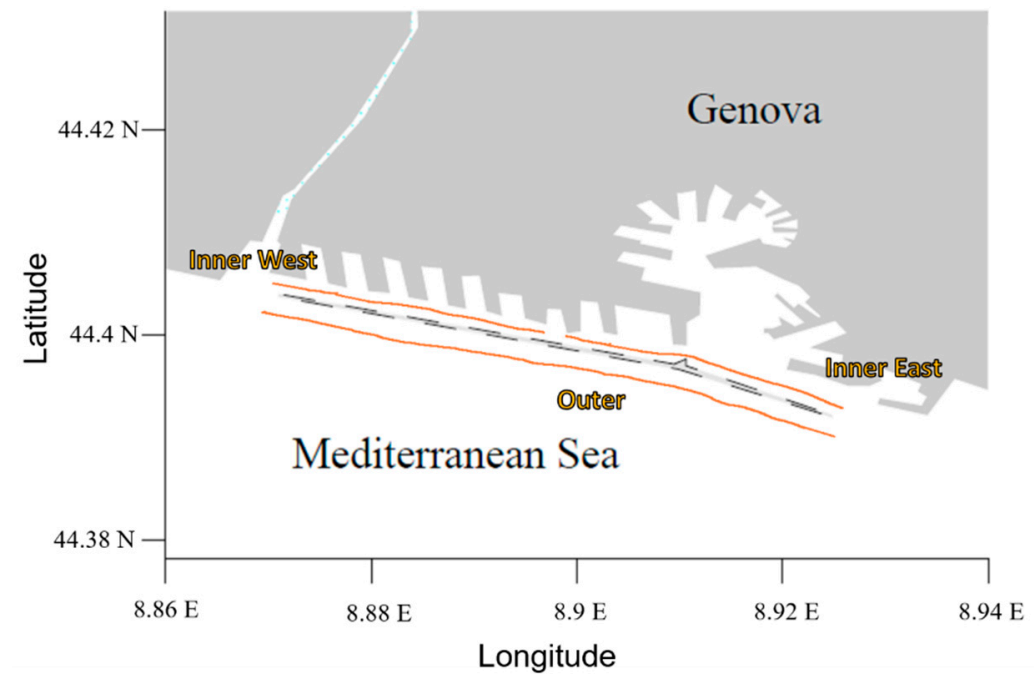

(b)

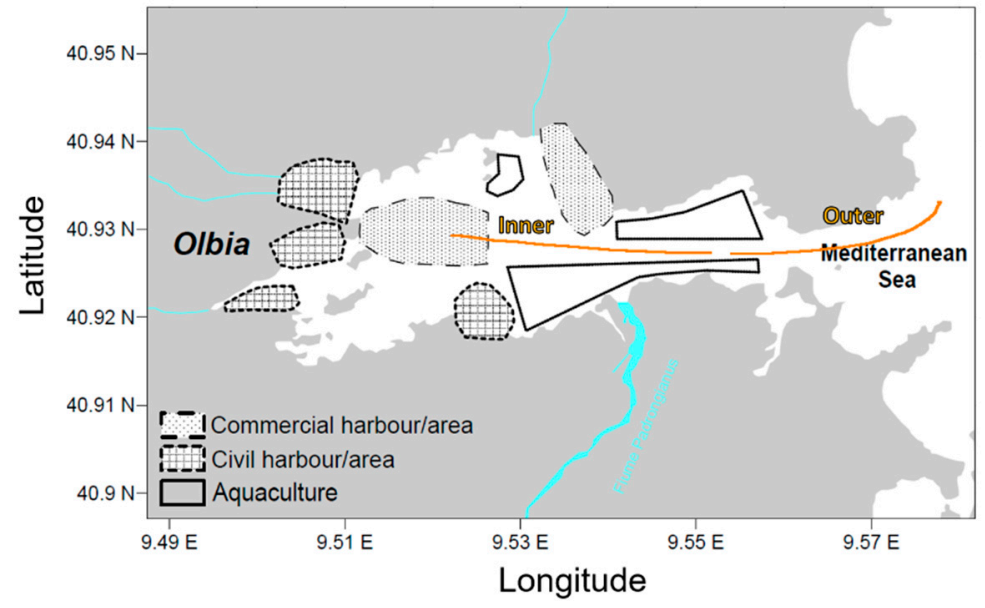

(c)

Figure 1. Sampling locations (a) Toulon, (b) Genova and (c) Olbia, with orange lines representing the performed transects. 
Genova is located in the north-western Italy and hosts an urban area reaching 580,000 inhabitants. The inner harbor waters are separated from the open sea by a seawall, with eastern and western entrances, and the inner harbor also hosts the river Sampierdarena channel (Figure 1). There is a wide range of activities inside the harbor. The western harbor hosts the majority of industrial activities, with a coal power plant, ore tanker, chemical, steel and container terminals (http:/ / www.porto.genova.it/ (accessed on 16 December 2020).

In addition, the Polcevera river, with a catchment surface area of $140 \mathrm{~km}^{2}$, flows in the western part of the harbor. The eastern harbor is influenced by the Bisagno river with a catchment surface area of $93 \mathrm{~km}^{2}$ [19] and also hosts industrial and commercial activities with dry docks, shipyards and a ferry terminal.

Olbia is located in the north-eastern Sardinia (Italy) with an urban area of 60,000 inhabitants. The harbor hosts a ferry terminal, an industrial zone dock, a marina and mussel cultures. The Padrogiano river with a drainage basin of $450 \mathrm{~km}^{2}$, flows to the northern area of the harbor (Figure 1).

Sampling transects ( $n=1$ per season) were performed in the inner and outer areas of each harbor (Orange lines, Figure 1). Microplastics were collected from surface water using a Manta net with a $60 \times 16 \mathrm{~cm}$ rectangular mouth and $300 \mu \mathrm{m}$ mesh. Manta net was trawled in the seawater surface (first $10 \mathrm{~cm}$ ) for $30 \mathrm{~min}$ to $1 \mathrm{~h}$ with a speed of 2.5 knots. To recover MPs, the manta net was gently rinsed with surface seawater, flushing all the fragments inside a collector. The sampled surface was calculated by measuring the distance between the beginning and the end of the sampling using a GPS tracker and multiplying it by the net opening area width. This allows us to calculate a quantity of MP items as a function of surface, hereafter labelled as areal concentration, or a mass of MPs as a function of surface, hereafter labelled mass areal concentration. In addition, the water volume was calculated by multiplying the sampled surface by the immersed net opening length corresponding to $10 \mathrm{~cm}$.

The samples were transferred into 1 L Pyrex bottle with surface seawater (locally sampled) and stored at $-20^{\circ} \mathrm{C}$ until analysis [20]. Unlike the other harbours, in Genova, the sample also contained some pieces of macroplastics (sizes ranging between 30 and $100 \mathrm{~mm}$ ) of different composition (bottle ring, rubber band, film, ... ). In order to assess the relationship between plastics sizes and trace metal bioconcentration, these pieces were kept and processed the same manner as for MPs. Inorganic contaminants in MPs and macroplastics were compared to determine the bioaccumulation according to surface size.

\subsection{Sample Treatment}

The first step of sample treatment consisted of a visual identification and separation of microplastics, with a binocular loupe (Leika) and trace metal clean forceps, thanks to their shape, color, opacity and texture. As a matter of fact, for the size range studied here (>300 $\mu \mathrm{m})$, polymer particles are generally straightforward to discriminate from mineral or vegetal particles by an experienced operator on the basis of brightness, hardness, stiffness and absence of striation [21].

Then, for each sample, all the collected MPs were gathered, and immersed for $24 \mathrm{~h}$ into $5 \mathrm{~mL}$ of a $0.1 \mathrm{M} \mathrm{NaOH}$ solution (30\%, suprapur) to extract the MPs biofilm. After immersion, the solution was filtered through $0.2 \mu \mathrm{m}$ cellulose acetate syringe filters (Sartorius, Minisart, Goettingen, Germany). Then $4.5 \mathrm{~mL}$ MilliQ water and $500 \mu \mathrm{L}$ of peroxide hydrogen (30\%, suprapur) were added to the solution which was irradiated in a UV-digester (Metrohm, Herisau, Switzerland) for $12 \mathrm{~h}$. The recovered extract was acidified with $\mathrm{HCl}$ (37\%, suprapur) for preservation and trace metals were analyzed using an ICP-MS (Perkin Elmer NexIon 300X, Waltham, MA, USA).

After biofilm digestion and separation from the solution through filtering, the dried fragments were weighed and one-by-one digitally recorded using a Zooscan V4, version 2.4.0. This technology was initially designed for zooplankton and phytoplankton identification and has recently been adapted for microplastics identification [22]. Using the 
web application Ecotaxa (ecotaxa.obs-vlfr.fr), counting, maximum length and surface were determined. Based on their length, MPs were partitioned according to the following size classes: $300-500 \mu \mathrm{m}, 500-1000 \mu \mathrm{m}, 1-2 \mathrm{~mm}, 2-3 \mathrm{~mm}, 3-4 \mathrm{~mm}, 4-5 \mathrm{~mm}$ by site. The influence of the season and sites on MPs areal concentrations, class distribution and inorganic contaminants was tested by one-way ANOVA (F) or non-parametric Kruskal-Wallis tests $(\mathrm{H})$ after checking normal distribution and homogeneity of variance.

\section{Results and Discussion}

\subsection{Microplastics Areal Concentrations in the North-Western Mediterranean Harbors}

In this study, the minimal (5576 items $\left.\cdot \mathrm{km}^{-2}\right)$ and maximal $\left(379,965\right.$ items $\left.\cdot \mathrm{km}^{-2}\right)$ areal concentrations were observed in Genova during cold and warm seasons, respectively. The detailed results are presented below (Table 1; Figure 2; Figure S1).

Table 1. Number, areal and mass areal concentrations of microplastics at different sites (TLN: Toulon, GEN: Genova and OLB: Olbia), seasons (W: winter and S: summer) and zones (Inner and Outer).

\begin{tabular}{|c|c|c|c|c|c|c|c|}
\hline Site & Season & Zone & $\begin{array}{l}\text { Volume } \\
{\left[\mathrm{m}^{3}\right]}\end{array}$ & $\begin{array}{c}\text { Surface } \\
{\left[\mathrm{m}^{2}\right]}\end{array}$ & Items & $\begin{array}{l}\text { Concentrations } \\
\text { [Items } \cdot \mathbf{k m}^{-2} \text { ] }\end{array}$ & {$\left[\mathrm{g} \cdot \mathrm{km}^{-2}\right]$} \\
\hline \multirow{2}{*}{ TLN } & \multirow{2}{*}{ W } & Inner & 217 & 2166 & 54 & 24,931 & 36.00 \\
\hline & & Outer & 164 & 1644 & 10 & 6083 & 0.06 \\
\hline \multirow{2}{*}{ TLN } & \multirow{3}{*}{ S } & Inner & 167 & 1666 & 68 & 40,816 & 33.20 \\
\hline & & Outer & 213 & 2128 & 61 & 28,665 & 8.18 \\
\hline \multirow{3}{*}{ GEN } & & Inner-West & 180 & 1800 & 41 & 22,778 & 15.00 \\
\hline & \multirow[t]{2}{*}{ W } & Inner-East & 168 & 1680 & 19 & 11,310 & 9.30 \\
\hline & & Outer & 323 & 3228 & 18 & 5576 & 1.90 \\
\hline \multirow{2}{*}{ GEN } & \multirow{2}{*}{ S } & Inner-West & 136 & 1158 & 440 & 379,965 & 551.00 \\
\hline & & Outer & 116 & 1362 & 80 & 58,737 & 130.00 \\
\hline \multirow{2}{*}{ OLB } & \multirow[b]{2}{*}{ W } & Inner & 174 & 1736 & 100 & 57,604 & 6.96 \\
\hline & & Outer & 155 & 1547 & 26 & 16,807 & 0.36 \\
\hline
\end{tabular}

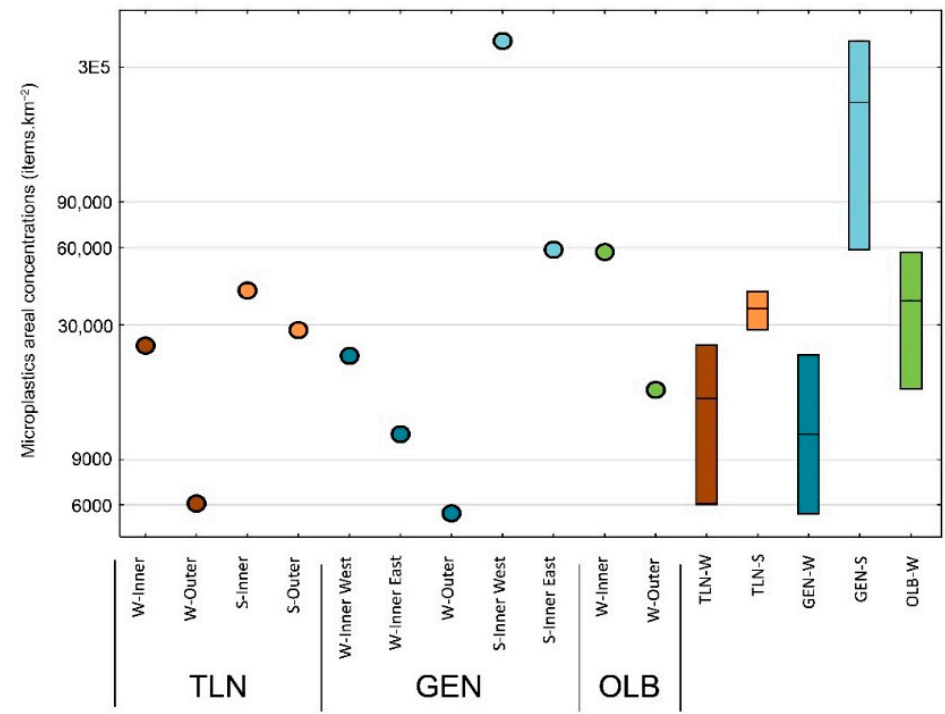

Figure 2. Areal concentrations of microplastics at different sites (TLN: Toulon, in orange, GEN: Genova, in blue and OLB: Olbia, in green), seasons (W: winter, in dark color and S: summer, in light color) and zones (Inner and Outer). The box-plots at right represent the interquartile range for each site and season with the median represented by an horizontal line.

The measured areal concentrations were in the same range as those observed in other locations close to urban agglomerations in the north-western Mediterranean coast: 70,000 items $\cdot \mathrm{km}^{-2}$ in Cartagena [23], 96,103 items $\cdot \mathrm{km}^{-2}$ and 123,846 items $\cdot \mathrm{km}^{-2}$ in Toulon, 
206,845 items $\cdot \mathrm{km}^{-2}$ in Nice and 169,186 items $\cdot \mathrm{km}^{-2}$ in Genova [10] and 112,000 items $\cdot \mathrm{km}^{-2}$ in Marseille [24]. The mass areal concentration average ranged between 0.06 and $551 \mathrm{~g} \cdot \mathrm{km}^{-2}$.

The comparison between the three studied harbors was only possible during the cold season because of a lack of data for Olbia during summer.

The maximum average areal concentrations found in Olbia are probably related to a higher drainage basin $\left(450 \mathrm{~km}^{2}\right)$ of the river flowing into the harbor with respect to those in Toulon $\left(60 \mathrm{~km}^{2}\right.$ and $\left.70 \mathrm{~km}^{2}\right)$ and Genova $\left(140 \mathrm{~km}^{2}\right.$ and $\left.93 \mathrm{~km}^{2}\right)$. In addition, the storm Amelie, an intense episode of Mediterranean rainfall, happened in the north-western Mediterranean basin during November, previous to sampling, which probably increased the river discharge and consequently MPs inputs. Indeed, land run-off can be an important source of MPs to the sea, carried out by rivers [25].

\subsection{Spatial Variability of Microplastics Areal Concentrations in the North-Western Mediterranean Harbors}

The inner zones of the harbors presented an average value higher than the outer parts, with $85,163 \pm 131,217$ items $\cdot \mathrm{km}^{-2}(n=7)$ and 14,283 $\pm 10,897 \mathrm{items} \cdot \mathrm{km}^{-2}(n=4)$, respectively $(\mathrm{H}=3.571, p=0.059)$. Microplastic areal concentrations in the inner harbor areas were systematically between 3 and 4 times higher than the outer parts, in all the studied harbors. The impact of industrialized and urbanized areas regarding MPs areal concentrations within both water columns and sediments has already been pointed out between inner and outer harbor [10,26-28], thus explaining the difference of MPs in this study, from inshore to offshore waters. In addition, harbors are semi-enclosed systems, where plastic waste and water masses can have longer residence times with respect to open waters, increasing the number of MPs. Hence, the higher areal concentrations observed in the inner harbor support the hypothesis of the potential contribution of harbors to MPs inputs into marine environments.

Microplastics in the Genova harbor were sampled in two zones (Inner east and Inner west) to assess the impact of different anthropogenic activities. The influence of the Polcevera river to the western part of the channel [19] and the outflow from the inner harbor caused by the northern winds [29] could have enhanced the areal concentrations observed in the western part of the Genova harbor in comparison to the eastern part, during both the warm $\left(58,737\right.$ items $\cdot \mathrm{km}^{-2}$ in the east and 379,965 items $\cdot \mathrm{km}^{-2}$ in the west) and the cold seasons $\left(11,310\right.$ items $\cdot \mathrm{km}^{-2}$ in the east and 22,778 items $\cdot \mathrm{km}^{-2}$ in the west).

\subsection{Influence of Seasonality on Microplastics Areal Concentrations}

The season has a significant impact on MPs areal concentrations. The reported values were significantly higher during summer than winter, with $127,046 \pm 169,065$ items $\cdot \mathrm{km}^{-2}$ $(n=4)$ and $20,727 \pm 17,934$ items $\cdot \mathrm{km}^{-2}(n=7)$, respectively $(\mathrm{H}=5.14, p<0.05)$. More specifically, in the bay of Toulon, between winter and summer, MPs areal concentrations increased up to 2 and 5 times in the inner and the outer harbor, respectively. Likewise, in Genova, an increase up to 5 and 17 times in the eastern and western zones was observed, respectively.

The increase of MPs areal concentrations observed during summer can be related to an enhancement of the activity. In fact, the number of passengers reported for December 2018 and March 2019 in Genova were 124,310 and 410,601 (http:/ / www.porto.genova.it (accessed on 16 December 2020)) and 44,802 and 237,693 in Toulon (CCI-Var), respectively. In addition, the more important number of passengers recorded in Genova, which reflect more numerous activities than in Toulon harbor, can explain the observed maximal MPs areal concentrations in the area, during this study. Harbor activities can influence MPs areal concentrations in different ways: firstly, acting as a local source of plastic litter to surface waters [9,30]; secondly, by resuspending MPs occurring in bottom waters and/or deposited on sediments [31], due to dredging operations and maritime transport in shallow waters.

Conversely, rivers which are the main source of MPs to the coastal waters, present an inverse seasonality, with higher areal concentrations and more important inputs during the 
cold season [25,30,32,33]. The higher concentrations observed after an episodic Mediterranean rainfall during winter in Olbia supports the role of rivers as sources of MPs during the wet season. Jimenez-Castro et al. [34] suggested a correlation between plastic litter and water discharge in the Rhône river and pointed rivers as major sources.

In this study, higher areal concentrations were reported, in contrast, during summer and highlighted harbors as a local major source, especially during summer.

\subsection{Size Distribution of Microplastics in the North-Western Mediterranean Harbors}

During this study, the lower and upper size limits considered for MPs identification were $300 \mu \mathrm{m}$ and $5 \mathrm{~mm}$, respectively. This range is within the limits recommended by Cutroneo et al. [20] for sampling MPs in port environments and are in agreement with the guidance lines of the Marine Strategy Framework Directive, Technical Subgroup on Marine Litter [35]. The class size distribution of MPs can gain insight regarding the proximity of MPs sources, their dynamics [36] and thus their potential influence on marine organisms [21], which is critical for a better characterization of MPs pollution.

In Toulon, MPs partitioning exhibited a maximal contribution of the $300-500 \mu \mathrm{m}$ class during winter ( $31 \%$ of the total fraction) and of the $2000-3000 \mu \mathrm{m}$ class during summer (26\% of the total fraction). In Genova, whatever the sampling season, the 2000-3000 $\mu \mathrm{m}$ class was always the most represented: $29 \%$ of the total fraction during winter and $32 \%$ during summer. In Olbia, data are available only for the winter period, and the most represented fraction was the $500-1000 \mu \mathrm{m}$ class: $38 \%$ of the total fraction. Significant differences between MPs size classes were only observed in Genova $(F=4.90, p<0.05)$ (Table S1, Figure 3).

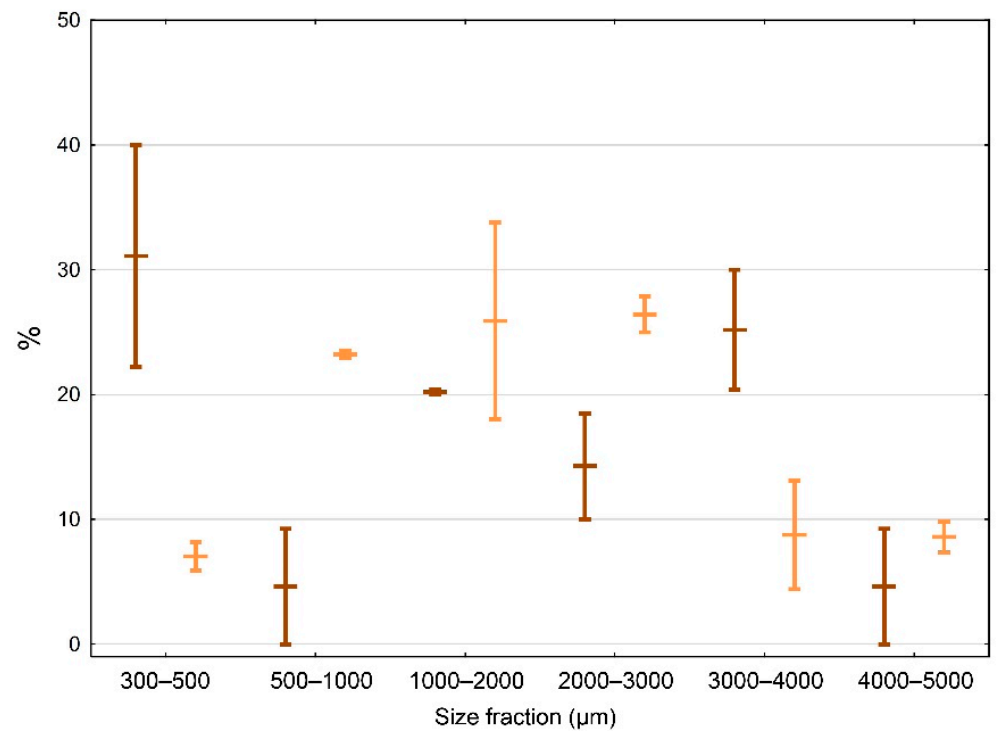

(a)

Figure 3. Cont. 


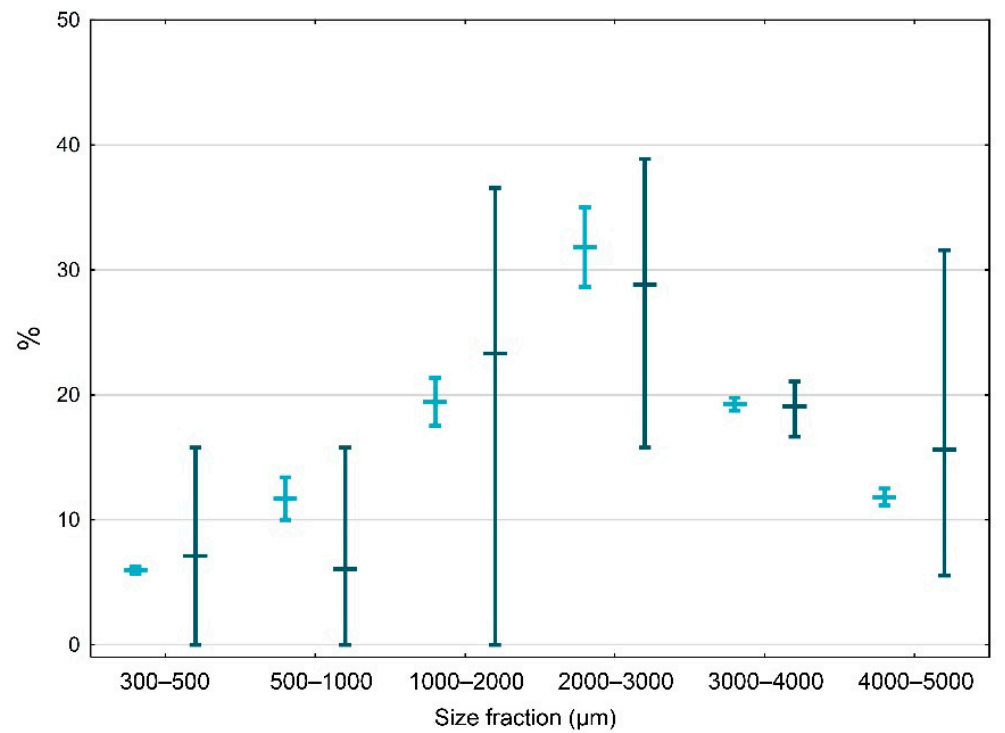

(b)

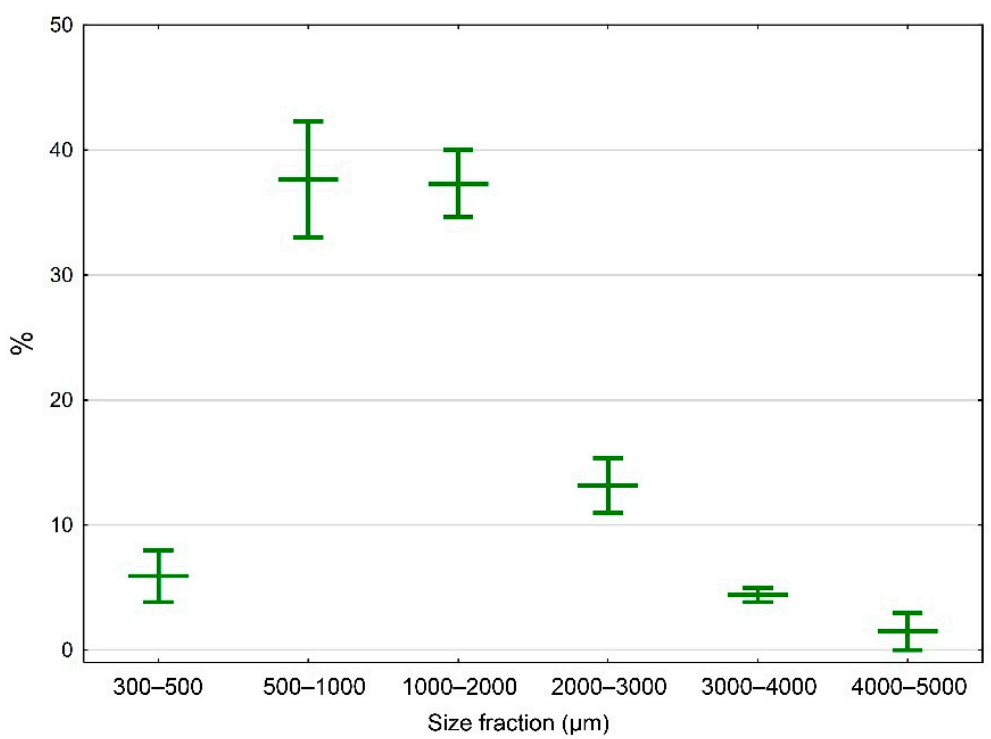

(c)

Figure 3. Percentage of contribution of microplastics size fraction (300-500 $\mu \mathrm{m}, 500-1000 \mu \mathrm{m}$, 1000-2000 $\mu \mathrm{m}, 2000-3000 \mu \mathrm{m}, 3000-4000 \mu \mathrm{m}$ and 4000-5000 $\mu \mathrm{m}$ ) to the total sampled fraction $(>300 \mu \mathrm{m})$ at the different sites (a) TLN: Toulon, (b) GEN: Genova and (c) OLB: Olbia and seasons (W: winter and S: summer). Average is represented by horizontal bars and minimum and maximum values represented by whiskers.

In this study, during winter, Toulon samples showed an overrepresentation of the small classes $(300-500 \mu \mathrm{m})$ in the inner and the outer part, contributing in average to $31 \%$ to the total fraction of MPs sampled (Figure 3). The predominance of small classes in surface waters during winter may be related to the mixing of the water column, most likely occurring during winter, thus leading to their upward dynamics and/or resuspension. Conversely, as a result of this water column mixing, higher MPs size classes which are buoyant can be transferred into the bottom waters through convective movements, constraining their sampling. The overrepresentation of small classes in bottom waters observed in estuaries supports this hypothesis [37]. Therefore, episodic storms can influence MPs size distribution in the water column and consequently their transfer to marine organisms. 
In most of the samples, except Toulon during winter, low and high MPs size classes are underrepresented, intermediate ones being predominant, a result already reported in previous studies $[10,24,37,38]$. The overrepresentation of intermediate classes may be related to degradation of high size classes into smaller fragments [39]. Many factors can drive degradation including photooxidation, biodegradation, thermo-oxidation, hydrolysis, thermal and mechanical stress [40]. As a result, an exponential increase of MPs areal concentration is expected, following the decrease of MPs size. This low representativeness of small MPs size class may reflect a continuous degradation spectrum of MPs, resulting in size fraction lower than the net mesh size $(300 \mu \mathrm{m})$, and are consequently not sampled, underestimating small classes of MPs [21,41]. However, the most common explanation is linked to the sinking of MPs due to an increase of their specific surface alongside to their colonization by microorganisms and biofilm growth, modifying their buoyancy $[38,42,43]$.

Although size class distributions fluctuated between harbors, a similar MPs size class distribution was observed for the outer and inner part of each harbor, suggesting that MPs sampled in the outer zones were very probably transferred from the inner parts. The different size distributions observed between the three sites may be linked to a sourcedependent signature. The higher MPs size classes, more frequent in Genova, indicated fresh and nearby sources probably related to the harbor activities and lower residence time [24]. Microplastics may have been transported and deposited by the waves, exposed to degradation and reintroduced [36].

This size class determination is linked to a potential impact. Due to their small dimensions, small MPs size fraction can be easily confused with sources of food and thereby be ingested by organisms [44]. The size classes sampled during this study are in the range of MPs sizes reported to be ingested by aquatic organisms [45,46]. In addition to their direct impact, one can ask the additional impact of the metal load of the MPs.

\subsection{Inorganic Contaminants}

The biofilm covering the MPs has been extracted to analyze trace metal contaminants. The average concentrations reported during the project were $4.8 \pm 4.5 \mathrm{mg} \cdot \mathrm{kg}^{-1}$ for $\mathrm{Pb}, 2371 \pm 7636 \mathrm{mg} \cdot \mathrm{kg}^{-1}$ for Fe, $13 \pm 14 \mathrm{mg} \cdot \mathrm{kg}^{-1}$ for $\mathrm{Cu}, 2.96 \pm 6.18 \mathrm{mg} \cdot \mathrm{kg}^{-1}$ for $\mathrm{V}$, $380 \pm 988 \mu \mathrm{g} \cdot \mathrm{kg}^{-1}$ for Cd, $479 \pm 293 \mu \mathrm{g} \cdot \mathrm{kg}^{-1}$ for As. (Table 2, Figure S2).

Table 2. Trace metal mass-related concentrations in biofilm extracted from microplastics at the different sites (TLN: Toulon, GEN: Genova and OLB: Olbia), seasons (W: winter and S: summer), zones (Inner and Outer). F = ANOVA's Fisher statistics and $p=p$-value.

\begin{tabular}{|c|c|c|c|c|c|c|c|}
\hline Sample & Site & $\begin{array}{c}\mathrm{Pb} \\
\mathrm{mg} \cdot \mathrm{kg}^{-1}\end{array}$ & $\underset{\mathrm{mg} \cdot \mathrm{kg}^{-1}}{ }$ & $\underset{\mathrm{mg} \cdot \mathrm{kg}^{-1}}{\mathrm{Cu}}$ & $\begin{array}{c}\mathrm{V} \\
\mathrm{mg} \cdot \mathrm{kg}^{-1}\end{array}$ & $\underset{\mu \mathrm{g} \cdot \mathrm{kg}^{-1}}{\mathrm{Cd}}$ & $\begin{array}{c}\text { As } \\
\mu \mathrm{g} \cdot \mathrm{kg}^{-1}\end{array}$ \\
\hline TLN-W-Inner & TLN & 1.8 & 22 & 2.54 & 1.53 & 3 & 862 \\
\hline TLN-W-Outer & & $<\mathrm{DL}$ & 181.8 & 46 & 1.982 & 2821 & 400.11 \\
\hline TLN-S-Inner & & 0.66 & 8 & 15.1 & 1.11 & 24 & 444.35 \\
\hline TLN-S-Outer & & 2.08 & 71.3 & 2.57 & 1.087 & 9.98 & 504 \\
\hline GEN-W-Inner West & GEN & 11.72 & 89.76 & 6 & 2.152 & $<\mathrm{DL}$ & 185 \\
\hline GEN-W-Inner East & & 3.78 & 37.6 & 12.74 & 0.4 & $<\mathrm{DL}$ & $<\mathrm{DL}$ \\
\hline GEN-W-Outer & & 7.97 & 187 & 23.3 & 1.25 & $<\mathrm{DL}$ & $<\mathrm{DL}$ \\
\hline GEN-S-Inner West & & 1.342 & 10 & 3.2 & 0.7 & 5.2 & 273 \\
\hline GEN-S-Inner East & & 1.89 & 5.2 & 3.25 & 0.51 & 0.96 & 211 \\
\hline OLB-W-Inner & OLB & 3.79 & 80.4 & 0.728 & 0.309 & 1.7 & 258 \\
\hline OLB-W-Outer & & 12.98 & 25,393 & 29.6 & 21.5 & 176 & 969 \\
\hline Analysis of variance & $\begin{array}{l}\mathrm{H}=4.06 \\
p=0.131\end{array}$ & $\begin{array}{l}\mathrm{H}=2.00 \\
p=0.367\end{array}$ & $\begin{array}{l}\mathrm{H}=0.06 \\
p=0.968\end{array}$ & $\begin{array}{l}\mathrm{H}=0.65 \\
p=0.720\end{array}$ & $\begin{array}{l}\mathrm{H}=2.00 \\
p=0.367\end{array}$ & $\begin{array}{l}\mathrm{H}=4.31 \\
p=0.115\end{array}$ & \\
\hline
\end{tabular}

Regulations of quality guidelines [47] can be used to determine the toxicity levels of the studied contaminants. Concerning lead, whatever the studied site and the season, the measured concentrations were always below the recommended guideline values for sediment 
(sediment quality guideline value of $50 \mathrm{mg} \cdot \mathrm{kg}^{-1}$ and Predicted No Effect Concentration of $\left.53.4 \mathrm{mg} \cdot \mathrm{kg}^{-1}\right)$. Yet, when compared with recommended concentrations reported in bivalves (CE No 1881/2006, commission on the 19 December 2006), lead exceeded the limit of $1.5 \mathrm{mg} \cdot \mathrm{kg}^{-1}$ in half of the samples in Toulon, in almost all collected samples in Genova and the totality of those collected in Olbia. Concerning copper, whatever the studied site and the season, the measured concentrations were always below the recommended quality guideline value for sediment $\left(65 \mathrm{mg} \cdot \mathrm{kg}^{-1}\right)$ but always above the recommended ecotoxicology guideline value for sediment (Predicted No Effect Concentration of $0.8 \mathrm{mg} \cdot \mathrm{kg}^{-1}$ ). Concerning cadmium, whatever the studied site and the season, the measured concentrations were always below the recommended guideline value for sediment (sediment quality guideline value of $1.5 \mathrm{mg} \cdot \mathrm{kg}^{-1}$ and Predicted No Effect Concentration of $2.3 \mathrm{mg} \cdot \mathrm{kg}^{-1}$ ) and also below the No Effect Concentration for benthic organism $\left(115 \mathrm{mg} \cdot \mathrm{kg}^{-1}\right)$. Yet, when compared with recommended concentrations reported in bivalves (CE No 1881/2006, commission on the 19 December 2006), cadmium exceeded the limit of $1 \mathrm{mg} \cdot \mathrm{kg}^{-1}$ in one case, during winter in the outer part of the Toulon bay. Concerning arsenic, whatever the studied site and the season, the measured concentrations were always below the recommended guideline value for sediment (sediment quality guideline value of $20 \mathrm{mg} \cdot \mathrm{kg}^{-1}$ ) but always equal or above the quality value for benthic organisms $\left(230 \mu \mathrm{g} \cdot \mathrm{kg}^{-1}\right)$. The results therefore demonstrated an important bioaccumulation that should, in many cases, impact on the biofilm and the ecosystems.

Considering the typical orders of magnitude of dissolved trace elements in the north-Mediterranean coastal waters [48-50], the average bioconcentration factors (BCF) reported during this study in Toulon were $1.37 \times 10^{5} \mathrm{~L} \cdot \mathrm{kg}^{-1}$ for $\mathrm{Pb}, 8.01 \times 10^{5} \mathrm{~L} \cdot \mathrm{kg}^{-1}$ for $\mathrm{Fe}, 1.47 \times 10^{5} \mathrm{~L} \cdot \mathrm{kg}^{-1}$ for $\mathrm{Cu}, 1.66 \times 10^{3} \mathrm{~L} \cdot \mathrm{kg}^{-1}$ for $\mathrm{V}, 4.76 \times 10^{4} \mathrm{~L} \cdot \mathrm{kg}^{-1}$ for $\mathrm{Cd}$ and $3.51 \times 10^{2} \mathrm{~L} \cdot \mathrm{kg}^{-1}$ for As (Table S2). These bioconcentration factors of inorganic contaminants, ranging between $10^{2}$ to $10^{6} \mathrm{~L} \cdot \mathrm{kg}^{-1}$, reflected at least two orders of magnitude between dissolved and particulate phase (water and biofilm), a partitioning already reported for biofilms [51,52]. Therefore, biofilm is most likely responsible for trace metal concentrations through biosorption at the surface of MPs [14,16]. In a previous study [53], most of the metals were removed after washing MPs with $\mathrm{NaOH}$, suggesting larger amounts of trace metals associated with biofilm than those specific to MPs matrix. Whatever its composition and aspect, biofilm will always represent a narrow layer compared to MPs. Therefore, as the metal concentration was normalized in this study over the mass of MPs, it has to be underlined that this bioaccumulation may be largely underestimated if, rather than the MPs mass, the biofilm mass would be considered.

In general, the highest average inorganic contaminant concentrations were observed in Olbia, with higher concentrations for $\mathrm{Cd}$ and $\mathrm{Cu}$ occurring in Toulon. Genova presented the lowest concentrations in heavy metals reported during this study. Higher trace metal concentrations in surface sediments reported in Toulon with respects to Genova [19,54], evidencing a major impact of human activities in Toulon harbor, probably explained the observed differences. In fact, biofilm on MPs acts as a passive sampler reflecting the concentrations in surrounding waters $[15,55,56]$. Many factors can impact on trace metal biosorption such as the stage of maturity of the biofilm, MPs surface and physicochemical conditions of exposition ( $\mathrm{pH}$, salinity, temperature, oxygen, organic ligands ... ) [15]. Likewise, depending on the site, bacterioplankton communities have a different influence on trace metal mobilization in seawater [57]. Finally, the different concentrations can also be governed by the prevalence of small classes of MPs which present higher specific surfaces. In this study, in terms of trace metal concentrations, no difference was observed between inner and outer zones, probably due to the rapid modification of biofilm according to the surrounding waters.

In order to assess the relationship between MPs size and trace metal bioconcentration, inorganic contaminants in MPs were compared to those measured in macroplastics. Due to their different specific surface and to allow comparison, concentrations were normalized to their surface (Figure 4, Table S3). The concentration per surface area for micro and 
macroplastics collected in the harbor of Genova were, respectively, $34.7 \pm 16.3 \mathrm{ng} \cdot \mathrm{cm}^{-2}$ and $2.05 \pm 1.48 \mathrm{ng} \cdot \mathrm{cm}^{-2}$ for $\mathrm{Pb}, 368.7 \pm 356.5 \mathrm{ng} \cdot \mathrm{cm}^{-2}$ and $43.4 \pm 43.9 \mathrm{ng} \cdot \mathrm{cm}^{-2}$ for Fe, $65.7 \pm 36.7 \mathrm{ng} \cdot \mathrm{cm}^{-2}$ and $13.9 \pm 19.0 \mathrm{ng} \cdot \mathrm{cm}^{-2}$ for $\mathrm{Cu}, 7.40 \pm 3.21 \mathrm{ng} \cdot \mathrm{cm}^{-2}$ and $0.89 \pm 0.38 \mathrm{ng} \cdot \mathrm{cm}^{-2}$ for $\mathrm{V}, 38 \mathrm{pg} \cdot \mathrm{cm}^{-2}$ and $6.05 \mathrm{pg} \cdot \mathrm{cm}^{-2}$ for $\mathrm{Cd}, 2.69 \pm 1.67 \mathrm{ng} \cdot \mathrm{cm}^{-2}$ and $0.41 \pm 0.38 \mathrm{ng} \cdot \mathrm{cm}^{-2}$ for As.

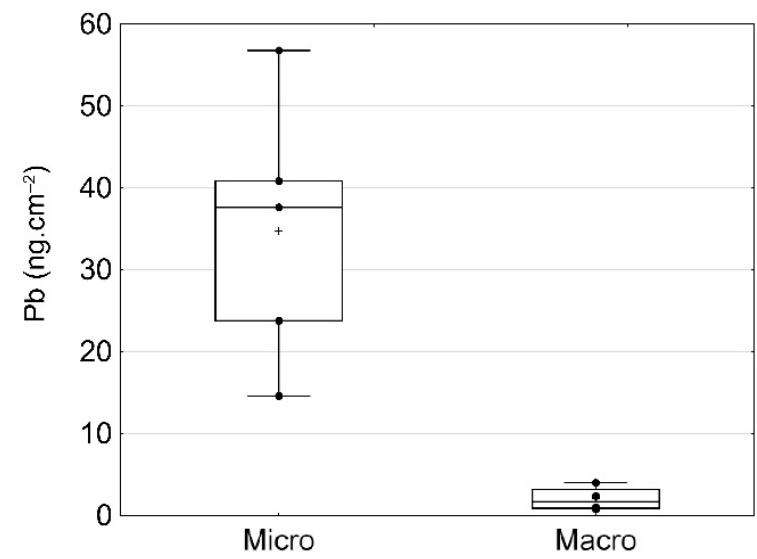

(a)

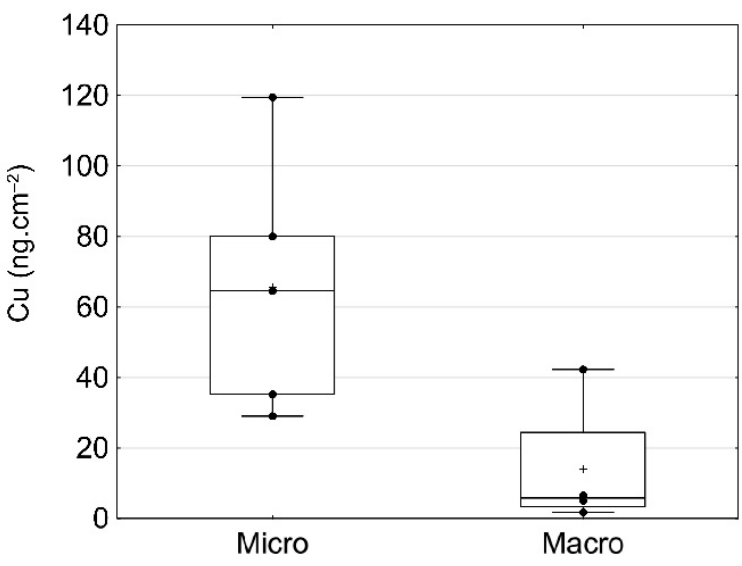

(c)

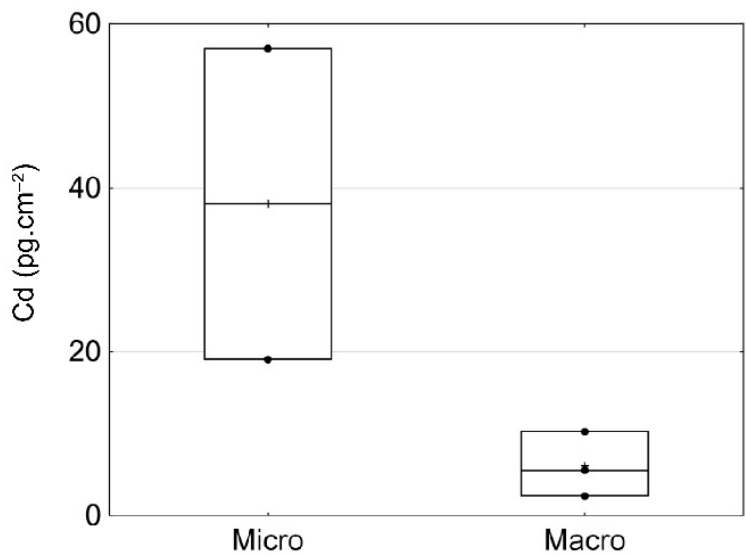

(e)

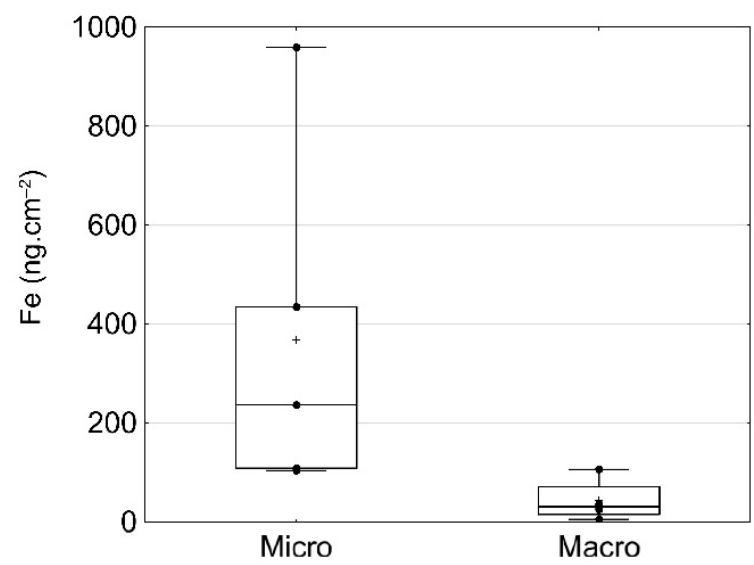

(b)

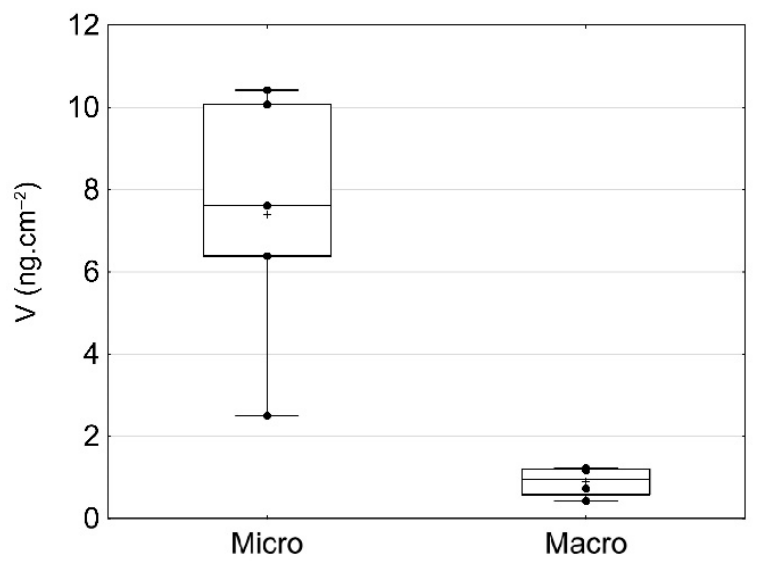

(d)

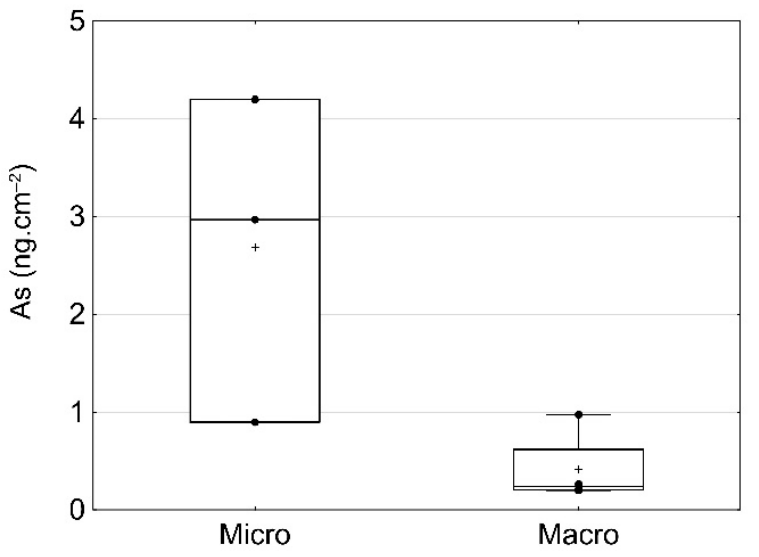

(f)

Figure 4. Boxplot of trace metal concentrations normalized over the surface of microplastics (Micro) and macroplastic (Macro) sampled in Genova. The average value is represented with a cross, the median is represented by an horizontal line while raw data is represented by black dots. The box length is defined as the interquartile range. (a) $\mathrm{Pb},(\mathbf{b}) \mathrm{Fe},(\mathbf{c}) \mathrm{Cu}$, (d) $\mathrm{V}$, (e) Cd, (f) As. 
Inorganic contaminants extracted from biofilm showed higher average concentrations in microplastics than macroplastics, with a significant difference for $\mathrm{Pb}, \mathrm{Fe}, \mathrm{Cu}$ and $\mathrm{V}$ (Table S3). Although the type of encountered MPs and macroplastics can weakly influence the sorption of trace metals [16], it has been recently shown that the biofilm stage of development highly influences trace metal bioaccumulation [15]. Indeed, a longer immersion favors bacteria colonization, leading to an increase in bioaccumulation efficiency [14,16,52]. For some metals, the amount of biofilm has been recently evidenced as well correlated with trace metals bioaccumulation [15]. Furthermore, an enhanced weathering of MPs is also susceptible to modify their surface properties, promoting biofouling $[58,59]$, thus trace metal sorption [60]. Therefore, in this study, higher trace metal concentrations observed in MPs could potentially reflect a longer exposition to environmental alterations and/or to bacteria, both leading to higher biofilm growth.

Although MPs areal concentrations can be low compared to particles in coastal environments, their positive buoyancy and currents are susceptible to transport them to open sea areas. Hence, trace metals associated with MPs can be released or ingested by organisms, affecting remote food webs [21,61,62].

Concerning the bay of Toulon, various studies $[18,63]$ have highlighted the presence of strong wind between $25 \%$ and $30 \%$ of the time, in a direction flushing away the waters from the harbor to the open sea [18]. Elsewhere, in the bay of Genova, during summer, the dominant south eastern winds divide the eastern port entrance in two opposite current directions flowing outwards in the south and inwards in the north. During winter, current flows outwards due to the northern winds [64]. When linking this to the results obtained in this study, it is therefore evident that such windy conditions would favor the dissemination of MPs from an area where they are more numerous and loaded with inorganic contaminants to the open sea.

\section{Conclusions}

Microplastic concentrations in the north-western Mediterranean harbors, including Genova, Olbia and Toulon, exhibited the same order of magnitudes as MPs concentrations reported in coastal Mediterranean waters. A decreasing gradient from inner areas to outer areas was systematically observed, evidencing harbors as an important source of MPs to open marine environments. In this study, seasonal differences were pointed out, evidencing higher concentrations during the summer period in relation with more intense harbor activities. Besides, during episodic storms, river and/or land-based sources were highlighted in this study as playing a major role in MPs inputs to the harbors.

Alongside MPs pollution, this study demonstrated that trace metal concentrations associated with these biofouled artificial micro-particles exceeded in some cases quality guidelines, potentially threatening marine organisms. Indeed, the semi enclosed dynamic of harbors constrains water exchanges with open seas, increasing exposure time of MPs to polluted waters. Therefore, harbors may promote biofilm-driven interactions between water and MPs. The export of the metal-loaded on MPs to the open sea needs to be underlined, as MPs export promotes a threat to sea life.

Supplementary Materials: The following are available online at https: / / www.mdpi.com/2077-131 2/9/3/337/s1. Figure S1: Microplastics digital records using a Zooscan. The upper figure refers to the sample collected in the inner part of the Genova harbor (GEN-S-Inner West) and, on the bottom, the sample collected in the inner part of Toulon harbor (TLN-S-Inner), both during summer, Figure S2: Boxplot of trace metal concentrations in MPs normalized over MPs mass in Toulon (TLN), Genova (GEN) and Olbia (OLB). The average value is represented with a horizontal bar while raw data is represented by black dots, Table S1: Percentage of contribution of microplastics size fraction (300-500 $\mu \mathrm{m}, 500-1000 \mu \mathrm{m}, 1000-2000 \mu \mathrm{m}, 2000-3000 \mu \mathrm{m}, 3000-4000 \mu \mathrm{m}, 4000-5000 \mu \mathrm{m})$ to the total sampled fraction $(>300 \mu \mathrm{m})$ at the different sites (TLN: Toulon, GEN: Genova and OLB: Olbia), zones (Inner and Outer) and seasons (W: winter and S: summer). Table S2: Bioconcentration factors (BCF) of trace metals in biofilm extracted from microplastics at the different sites (TLN: Toulon, GEN: Genova and OLB: Olbia), seasons (W: winter and S: summer), zones (Inner and outer). Table S3: Trace metal 
surface-related concentrations in biofilm extracted from microplastics and macroplastics in Genova. $\mathrm{H}=$ Kruskal-Wallis $\chi 2$ statistics, $\mathrm{F}=$ ANOVA's Fisher statistics and $p=p$-value.

Author Contributions: Conceptualization, J.A.T.O., K.D. and V.L.; methodology, J.A.T.O., K.D. and V.L.; validation, J.A.T.O., K.D. and V.L.; formal analysis, J.A.T.O., K.D. and V.L.; investigation, J.A.T.O., K.D., F.B., S.C., B.A. and L.C.; resources, J.A.T.O., K.D. and V.L.; data curation, J.A.T.O., K.D. and V.L.; writing-original draft preparation, J.A.T.O., K.D., S.M., V.L. and A.S.; writing—review and editing, J.A.T.O., K.D., V.L., S.M. and A.S.; visualization, J.A.T.O., K.D. and V.L.; supervision, A.S., G.B., M.C., S.M. and V.L.; project administration, A.S., G.B., M.C., S.M. and V.L.; funding acquisition, A.S., M.C., S.M. and V.L. All authors have read and agreed to the published version of the manuscript.

Funding: This research has been financially supported by the Project Splash! Stop alle Plastiche in $\mathrm{H} 20$ !, funded by the Interreg Italia-Francia Marittimo Program.

Institutional Review Board Statement: Not applicable.

Informed Consent Statement: Not applicable.

Data Availability Statement: Not applicable.

Acknowledgments: The authors wish to thank all the team of the Project "SPlasH!-Stop alle Plastiche in $\mathrm{H}_{2} \mathrm{O}^{\prime}$. The Authors thank the Port Authority of Genoa for giving them the possibility to carry out the present research in the Port of Genoa. The Authors thank CEREGE facilities for ICP-MS measurements. The authors specially thank Francesca Spotorno, Andrea Dorigo and all the members of the Servizi Ecologici Porto di Genova (SEPG) for their support with sampling in Genova as well as Simone Simeone and Alberto Ribotti for their support in Olbia.

Conflicts of Interest: The authors declare no conflict of interest. The funders had no role in the design of the study; in the collection, analyses or interpretation of data; in the writing of the manuscript or in the decision to publish the results.

\section{References}

1. Goldstein, M.C.; Rosenberg, M.; Cheng, L. Increased Oceanic Microplastic Debris Enhances Oviposition in an Endemic Pelagic Insect. Biol. Lett. 2012, 8, 817-820. [CrossRef]

2. Cole, M.; Lindeque, P.; Halsband, C.; Galloway, T.S. Microplastics as Contaminants in the Marine Environment: A Review. Mar. Pollut. Bull. 2011, 62, 2588-2597. [CrossRef] [PubMed]

3. Coll, M.; Piroddi, C.; Steenbeek, J.; Kaschner, K.; Ben Rais Lasram, F.; Aguzzi, J.; Ballesteros, E.; Bianchi, C.N.; Corbera, J.; Dailianis, T.; et al. The Biodiversity of the Mediterranean Sea: Estimates, Patterns, and Threats. PLoS ONE 2010, 5, e11842. [CrossRef]

4. Lotze, H.K.; Coll, M.; Dunne, J.A. Historical Changes in Marine Resources, Food-Web Structure and Ecosystem Functioning in the Adriatic Sea, Mediterranean. Ecosystems 2011, 14, 198-222. [CrossRef]

5. De Madron, X.D.; Guieu, C.; Sempéré, R.; Conan, P.; Cossa, D.; D’Ortenzio, F.; Estournel, C.; Gazeau, F.; Rabouille, C.; Stemmann, L.; et al. Marine Ecosystems' Responses to Climatic and Anthropogenic Forcings in the Mediterranean. Prog. Oceanogr. 2011, 91, 97-166. [CrossRef]

6. Cózar, A.; Sanz-Martín, M.; Martí, E.; González-Gordillo, J.I.; Ubeda, B.; Gálvez, J.Á.; Irigoien, X.; Duarte, C.M. Plastic Accumulation in the Mediterranean Sea. PLoS ONE 2015, 10, e0121762. [CrossRef]

7. Van Sebille, E.; Wilcox, C.; Lebreton, L.; Maximenko, N.; Hardesty, B.D.; van Franeker, J.A.; Eriksen, M.; Siegel, D.; Galgani, F.; Law, K.L. A Global Inventory of Small Floating Plastic Debris. Environ. Res. Lett. 2015, 10, 124006. [CrossRef]

8. Moore, C.J.; Moore, S.L.; Leecaster, M.K.; Weisberg, S.B. A Comparison of Plastic and Plankton in the North Pacific Central Gyre. Mar. Pollut. Bull. 2001, 42, 1297-1300. [CrossRef]

9. Jambeck, J.R.; Geyer, R.; Wilcox, C.; Siegler, T.R.; Perryman, M.; Andrady, A.; Narayan, R.; Law, K.L. Plastic Waste Inputs from Land into the Ocean. Science 2015, 347, 768-771. [CrossRef]

10. Pedrotti, M.L.; Petit, S.; Elineau, A.; Bruzaud, S.; Crebassa, J.-C.; Dumontet, B.; Martí, E.; Gorsky, G.; Cózar, A. Changes in the Floating Plastic Pollution of the Mediterranean Sea in Relation to the Distance to Land. PLoS ONE 2016, 11, e0161581. [CrossRef]

11. Ross, J.B.; Parker, R.; Strickland, M. A Survey of Shoreline Litter in Halifax Harbour 1989. Mar. Pollut. Bull. 1991, 22, 245-248. [CrossRef]

12. Glaser, J.A. The Importance of Biofilms to the Fate and Effects of Microplastics. In Bacterial Biofilms; Dincer, S., Sümengen Özdenefe, M., Arkut, A., Eds.; IntechOpen: London, UK, 2020. [CrossRef]

13. Flemming, H.-C.; Wingender, J. The Biofilm Matrix. Nat. Rev. Microbiol. 2010, 8, 623-633. [CrossRef]

14. Duong, T.T.; Morin, S.; Coste, M.; Herlory, O.; Feurtet-Mazel, A.; Boudou, A. Experimental Toxicity and Bioaccumulation of Cadmium in Freshwater Periphytic Diatoms in Relation with Biofilm Maturity. Sci. Total Environ. 2010, 408, 552-562. [CrossRef]

15. Richard, H.; Carpenter, E.J.; Komada, T.; Palmer, P.T.; Rochman, C.M. Biofilm Facilitates Metal Accumulation onto Microplastics in Estuarine Waters. Sci. Total Environ. 2019, 683, 600-608. [CrossRef] 
16. Rochman, C.M.; Hentschel, B.T.; Teh, S.J. Long-Term Sorption of Metals Is Similar among Plastic Types: Implications for Plastic Debris in Aquatic Environments. PLoS ONE 2014, 9, e85433. [CrossRef]

17. Roane, T.M.; Pepper, I.L.; Gentry, T.J. Microorganisms and Metal Pollutants. In Environmental Microbiology; Elsevier: Amsterdam, The Netherlands, 2015; pp. 415-439. [CrossRef]

18. Mazoyer, C.; Vanneste, H.; Dufresne, C.; Ourmières, Y.; Magaldi, M.G.; Molcard, A. Impact of Wind-Driven Circulation on Contaminant Dispersion in a Semi-Enclosed Bay. Estuar. Coast. Shelf Sci. 2020, 233, 106529. [CrossRef]

19. Cutroneo, L.; Carbone, C.; Consani, S.; Vagge, G.; Canepa, G.; Capello, M. Environmental Complexity of a Port: Evidence from Circulation of the Water Masses, and Composition and Contamination of Bottom Sediments. Mar. Pollut. Bull. 2017, 119, 184-194. [CrossRef] [PubMed]

20. Cutroneo, L.; Reboa, A.; Besio, G.; Borgogno, F.; Canesi, L.; Canuto, S.; Dara, M.; Enrile, F.; Forioso, I.; Greco, G.; et al. Correction to: Microplastics in Seawater: Sampling Strategies, Laboratory Methodologies, and Identification Techniques Applied to Port Environment. Environ. Sci. Pollut. Res. 2020, 27, 8938-8952. [CrossRef] [PubMed]

21. Covernton, G.A.; Pearce, C.M.; Gurney-Smith, H.J.; Chastain, S.G.; Ross, P.S.; Dower, J.F.; Dudas, S.E. Size and Shape Matter: A Preliminary Analysis of Microplastic Sampling Technique in Seawater Studies with Implications for Ecological Risk Assessment. Sci. Total Environ. 2019, 667, 124-132. [CrossRef]

22. Gorsky, G.; Ohman, M.D.; Picheral, M.; Gasparini, S.; Stemmann, L.; Romagnan, J.-B.; Cawood, A.; Pesant, S.; Garcia-Comas, C.; Prejger, F. Digital Zooplankton Image Analysis Using the ZooScan Integrated System. J. Plankton Res. 2010, 32, $285-303$. [CrossRef]

23. De Haan, W.P.; Sanchez-Vidal, A.; Canals, M. Floating Microplastics and Aggregate Formation in the Western Mediterranean Sea. Mar. Pollut. Bull. 2019, 140, 523-535. [CrossRef]

24. Schmidt, N.; Thibault, D.; Galgani, F.; Paluselli, A.; Sempéré, R. Occurrence of Microplastics in Surface Waters of the Gulf of Lion (NW Mediterranean Sea). Prog. Oceanogr. 2018, 163, 214-220. [CrossRef]

25. Moore, C.J.; Moore, S.L.; Weisberg, S.B.; Lattin, G.L.; Zellers, A.F. A Comparison of Neustonic Plastic and Zooplankton Abundance in Southern California's Coastal Waters. Mar. Pollut. Bull. 2002, 44, 1035-1038. [CrossRef]

26. Antonella, A.; Léa, D.; Alex, A.; Fabrizio, A.; Asunción, B.; Ilaria, C.; Lara, C.; Roberto, C.; Gaëlle, D.; Delphine, G.; et al. Floating Marine Macro Litter: Density Reference Values and Monitoring Protocol Settings from Coast to Offshore. Results from the MEDSEALITTER Project. Mar. Pollut. Bull. 2020, 160, 111647. [CrossRef]

27. Claessens, M.; Meester, S.D.; Landuyt, L.V.; Clerck, K.D.; Janssen, C.R. Occurrence and Distribution of Microplastics in Marine Sediments along the Belgian Coast. Mar. Pollut. Bull. 2011, 62, 2199-2204. [CrossRef]

28. Desforges, J.-P.W.; Galbraith, M.; Dangerfield, N.; Ross, P.S. Widespread Distribution of Microplastics in Subsurface Seawater in the NE Pacific Ocean. Mar. Pollut. Bull. 2014, 79, 94-99. [CrossRef]

29. Capello, M.; Cutroneo, L.; Castellano, M.; Orsi, M.; Pieracci, A.; Maria Bertolotto, R.; Povero, P.; Tucci, S. Physical and Sedimentological Characterisation of Dredged Sediments. Chem. Ecol. 2010, 26 (Suppl. 1), 359-369. [CrossRef]

30. Boucher, J.; Friot, D. Primary Microplastics in the Oceans: A Global Evaluation of Sources; IUCN International Union for Conservation of Nature: Gland, Switzerland, 2017. [CrossRef]

31. Zhang, H. Transport of Microplastics in Coastal Seas. Estuar. Coast. Shelf Sci. 2017, 199, 74-86. [CrossRef]

32. Auta, H.S.; Emenike, C.U.; Fauziah, S.H. Distribution and Importance of Microplastics in the Marine Environment: A Review of the Sources, Fate, Effects, and Potential Solutions. Environ. Int. 2017, 102, 165-176. [CrossRef]

33. Lebreton, L.C.M.; van der Zwet, J.; Damsteeg, J.-W.; Slat, B.; Andrady, A.; Reisser, J. River Plastic Emissions to the World's Oceans. Nat. Commun. 2017, 8, 15611. [CrossRef]

34. Castro-Jiménez, J.; González-Fernández, D.; Fornier, M.; Schmidt, N.; Sempéré, R. Macro-Litter in Surface Waters from the Rhone River: Plastic Pollution and Loading to the NW Mediterranean Sea. Mar. Pollut. Bull. 2019, 146, 60-66. [CrossRef]

35. Galgani, F.; Hanke, G.; Werner, S.; De Vrees, L. Marine Litter within the European Marine Strategy Framework Directive. ICES J. Mar. Sci. 2013, 70, 1055-1064. [CrossRef]

36. Isobe, A.; Uchida, K.; Tokai, T.; Iwasaki, S. East Asian Seas: A Hot Spot of Pelagic Microplastics. Mar. Pollut. Bull. 2015, 101, 618-623. [CrossRef] [PubMed]

37. Defontaine, S.; Sous, D.; Tesan, J.; Monperrus, M.; Lenoble, V.; Lanceleur, L. Microplastics in a Salt-Wedge Estuary: Vertical Structure and Tidal Dynamics. Mar. Pollut. Bull. 2020, 160, 111688. [CrossRef]

38. Cozar, A.; Echevarria, F.; Gonzalez-Gordillo, J.I.; Irigoien, X.; Ubeda, B.; Hernandez-Leon, S.; Palma, A.T.; Navarro, S.; Garciade-Lomas, J.; Ruiz, A.; et al. Plastic Debris in the Open Ocean. Proc. Natl. Acad. Sci. USA 2014, 111, 10239-10244. [CrossRef] [PubMed]

39. Weinstein, J.E.; Crocker, B.K.; Gray, A.D. From Macroplastic to Microplastic: Degradation of High-Density Polyethylene, Polypropylene, and Polystyrene in a Salt Marsh Habitat: Degradation of Plastic in a Salt Marsh Habitat. Environ. Toxicol. Chem. 2016, 35, 1632-1640. [CrossRef]

40. Andrady, A.L. Microplastics in the Marine Environment. Mar. Pollut. Bull. 2011, 62, 1596-1605. [CrossRef] [PubMed]

41. Lindeque, P.K.; Cole, M.; Coppock, R.L.; Lewis, C.N.; Miller, R.Z.; Watts, A.J.R.; Wilson-McNeal, A.; Wright, S.L.; Galloway, T.S. Are We Underestimating Microplastic Abundance in the Marine Environment? A Comparison of Microplastic Capture with Nets of Different Mesh-Size. Environ. Pollut. 2020, 265, 114721. [CrossRef] 
42. Wright, R.J.; Erni-Cassola, G.; Zadjelovic, V.; Latva, M.; Christie-Oleza, J.A. Marine Plastic Debris: A New Surface for Microbial Colonization. Environ. Sci. Technol. 2020, 54, 11657-11672. [CrossRef]

43. Kooi, M.; van Nes, E.H.; Scheffer, M.; Koelmans, A.A. Ups and Downs in the Ocean: Effects of Biofouling on Vertical Transport of Microplastics. Environ. Sci. Technol. 2017, 51, 7963-7971. [CrossRef]

44. Lehtiniemi, M.; Hartikainen, S.; Näkki, P.; Engström-Öst, J.; Koistinen, A.; Setälä, O. Size Matters More than Shape: Ingestion of Primary and Secondary Microplastics by Small Predators. Food Webs 2018, 17, e00097. [CrossRef]

45. Pellini, G.; Gomiero, A.; Fortibuoni, T.; Ferrà, C.; Grati, F.; Tassetti, A.N.; Polidori, P.; Fabi, G.; Scarcella, G. Characterization of Microplastic Litter in the Gastrointestinal Tract of Solea Solea from the Adriatic Sea. Environ. Pollut. 2018, 234, 943-952. [CrossRef]

46. Leslie, H.A.; Brandsma, S.H.; van Velzen, M.J.M.; Vethaak, A.D. Microplastics En Route: Field Measurements in the Dutch River Delta and Amsterdam Canals, Wastewater Treatment Plants, North Sea Sediments and Biota. Environ. Int. 2017, 101, 133-142. [CrossRef]

47. Simpson, S.; Batley, G.E. Sediment Quality Assessment: A Practical Guide, 2nd ed.; Simpson, S., Batley, G.E., Eds.; CSIRO Publishing: Clayton, Australia, 2015.

48. Laumond, F.; Copin-Montegut, G.; Courau, P.; Nicolas, E. Cadmium, Copper and Lead in the Western Mediterranean Sea. Mar. Chem. 1984, 15, 251-261. [CrossRef]

49. Orani, A.M.; Barats, A.; Zitte, W.; Morrow, C.; Thomas, O.P. Comparative Study on the Bioaccumulation and Biotransformation of Arsenic by Some Northeastern Atlantic and Northwestern Mediterranean Sponges. Chemosphere 2018, 201, 826-839. [CrossRef]

50. Sherrell, R.M.; Boyle, E.A. Zinc, Chromium, Vanadium and Iron in the Mediterranean Sea. Deep Sea Research Part A. Oceanogr. Res. Pap. 1988, 35, 1319-1334. [CrossRef]

51. Friese, K.; Mages, M.; Wendt-Potthoff, K.; Neu, T.R. Determination of Heavy Metals in Biofilms from the River Elbe by TotalReflection X-Ray Fluorescence Spectrometry. Spectrochim. Acta Part B At. Spectrosc. 1997, 52, 1019-1025. [CrossRef]

52. Tien, C.-J.; Chen, C.S. Patterns of Metal Accumulation by Natural River Biofilms during Their Growth and Seasonal Succession. Arch. Environ. Contam. Toxicol. 2013, 64, 605-616. [CrossRef] [PubMed]

53. Prunier, J.; Maurice, L.; Perez, E.; Gigault, J.; Pierson Wickmann, A.-C.; Davranche, M.; Halle, A. ter. Trace Metals in Polyethylene Debris from the North Atlantic Subtropical Gyre. Environ. Pollut. 2019, 245, 371-379. [CrossRef] [PubMed]

54. Tessier, E.; Garnier, C.; Mullot, J.-U.; Lenoble, V.; Arnaud, M.; Raynaud, M.; Mounier, S. Study of the Spatial and Historical Distribution of Sediment Inorganic Contamination in the Toulon Bay (France). Mar. Pollut. Bull. 2011, 62, 2075-2086. [CrossRef]

55. Holmes, L.A.; Turner, A.; Thompson, R.C. Adsorption of Trace Metals to Plastic Resin Pellets in the Marine Environment. Environ. Pollut. 2012, 160, 42-48. [CrossRef]

56. Ashton, K.; Holmes, L.; Turner, A. Association of Metals with Plastic Production Pellets in the Marine Environment. Mar. Pollut. Bull. 2010, 60, 2050-2055. [CrossRef] [PubMed]

57. Coclet, C.; Garnier, C.; Durrieu, G.; Omanović, D.; D’Onofrio, S.; Le Poupon, C.; Mullot, J.-U.; Briand, J.-F.; Misson, B. Changes in Bacterioplankton Communities Resulting From Direct and Indirect Interactions With Trace Metal Gradients in an Urbanized Marine Coastal Area. Front. Microbiol. 2019, 10, 257. [CrossRef]

58. Mato, Y.; Isobe, T.; Takada, H.; Kanehiro, H.; Ohtake, C.; Kaminuma, T. Plastic Resin Pellets as a Transport Medium for Toxic Chemicals in the Marine Environment. Environ. Sci. Technol. 2001, 35, 318-324. [CrossRef]

59. Artham, T.; Sudhakar, M.; Venkatesan, R.; Madhavan Nair, C.; Murty, K.V.G.K.; Doble, M. Biofouling and Stability of Synthetic Polymers in Sea Water. Int. Biodeterior. Biodegrad. 2009, 63, 884-890. [CrossRef]

60. Kalčíková, G.; Skalar, T.; Marolt, G.; Jemec Kokalj, A. An Environmental Concentration of Aged Microplastics with Adsorbed Silver Significantly Affects Aquatic Organisms. Water Res. 2020, 175, 115644. [CrossRef]

61. Koelmans, A.A.; Besseling, E.; Foekema, E.M. Leaching of Plastic Additives to Marine Organisms. Environ. Pollut. 2014, 187, 49-54. [CrossRef]

62. Brennecke, D.; Duarte, B.; Paiva, F.; Caçador, I.; Canning-Clode, J. Microplastics as Vector for Heavy Metal Contamination from the Marine Environment. Estuar. Coast. Shelf Sci. 2016, 178, 189-195. [CrossRef]

63. Layglon, N.; Misson, B.; Durieu, G.; Coclet, C.; D’Onofrio, S.; Dang, D.H.; François, D.; Mullot, J.-U.; Mounier, S.; Lenoble, V.; et al. Long-Term Monitoring Emphasizes Impacts of the Dredging on Dissolved $\mathrm{Cu}$ and $\mathrm{Pb}$ Contamination along with Ultraplankton Distribution and Structure in Toulon Bay (NW Mediterranean Sea, France). Mar. Pollut. Bull. 2020, 156, 111196. [CrossRef] [PubMed]

64. Cutroneo, L.; Castellano, M.; Pieracci, A.; Povero, P.; Tucci, S.; Capello, M. The Use of a Combined Monitoring System for Following a Turbid Plume Generated by Dredging Activities in a Port. J. Soils Sediments 2012, 12, 797-809. [CrossRef] 